\title{
PENGUNGKAPAN SUKARELA, FENOMENA IPO, DAN SIGNALLING FIRM VALUE
}

\author{
Enok Rusmanah \\ Fakultas Ekonomi Universitas Pakuan, Bogor \\ E-mail: enok.rusmanah@unpak.ac.id
}

\begin{abstract}
Abstrak
Fenomena ketika perusahaan melakukan penawaran saham untuk pertama kalinya di bursa saham sering membuat perusahaan tidak dapat mengumpulkan dana secara maksimal. Fenomena ini dipercaya disebabkan oleh adanya asimetri informasi antara perusahaan dan investor. Pengungkapan sukarela digunakan oleh manajer untuk mengurangi risiko akibat kurangnya informasi ini dengan cara mensinyalkan informasi privat mereka. Oleh karena itu, penelitian ini bertujuan untuk menganalisis pengungkapan sukarela dalam pensinyalan nilai perusahaan (signalling firm value). Variabel pengungkapan yang digunakan sebagai sinyal terdiri dari underwriter, auditor, ukuran perusahaan, dan persentase saham yang ditahan pemilik lama. Hasil penelitian terhadap perusahaan sampel dengan menggunakan alat analisis korelasi dan regresi serta tingkat signifikansi 0,05 menunjukkan bahwa underwriter, auditor, ukuran perusahaan, dan persentase saham yang ditahan pemilik lama tidak dapat dibuktikan memiliki hubungan yang signifikan dengan nilai pasar penutupan hari pertama ketika IPO sebagai proksi reaksi pasar. Namun dari hasil regresi ditemukan bukti bahwa ukuran perusahaan memiliki pengaruh terhadap nilai perusahaan dengan signifikansi 0,006. Kemudian hasil regresi berganda juga menunjukkan bahwa variabel-variabel lain bersama ukuran perusahaan memiliki pengaruh secara simultan terhadap nilai perusahaan, terbukti dengan hasil uji $\mathrm{F}$ yang lebih besar dari $\mathrm{F}$ tabel 2,004. Oleh karena itu dapat disimpulkan bahwa investor dalam pengambilan keputusan investasi tidak hanya menangkap satu sinyal informasi dari manajer, tetapi juga menangkap sinyal-sinyal lain sebagai bahan pertimbangan investasinya.
\end{abstract}

Kata Kunci: Pengungkapan Sukarela, IPO, Signalling, Firm Value

\section{Pendahuluan}

Salah satu keputusan yang diambil oleh manajer perusahaan untuk mendapatkan tambahan dana adalah melakukan penawaran saham di bursa saham atau go public. Manajer yang memutuskan untuk melakukan penawaran perdana di bursa saham bertujuan mendapatkan dana sesuai dengan kebutuhan proyek investasi perusahaannya. Namun, pada umumnya perusahaan tidak memperoleh dana sesuai dengan kebutuhan dikarenakan adanya fenomena-fenomena yang terjadi pada saat Initial Public Offering (IPO). Dua fenomena yang umum terjadi pada saat penawaran saham untuk pertama kali di bursa saham adalah terjadinya underpricing dan asimetri informasi (Balvers et.al., 1988, Grinblatt dan Hwang, 1989, Kim et.al., 1993, Firth dan LiauTan, 1998, Nurhidayati dan Indriantoro, 1998,
Indriani dan Marlia, 2014, Chua, 2014, Tsang dan Blevins, 2015, dan Alvarez-Otero dan Lopez-Iturriaga, 2018).

Underpricing merupakan fenomena yang umum terjadi di setiap bursa saham (Kim et.al, 1993). Underpricing terjadi ketika harga saham di pasar perdana lebih rendah daripada harga saham yang diperdagangkan di pasar sekunder (Indriani dan Marlia, 2013). Underpricing yang tinggi dari sisi emiten merugikan karena perusahaan dinilai terlalu rendah dari nilai yang sesungguhnya oleh underwriter, sedangkan bagi underwriter, underpricing dapat mengurangi risiko kerugian jika saham yang dijaminnya tidak laku di pasar (Nurhidayati dan Indriantoro, 1998). Berbagai penelitian mengenai underpricing menemukan bahwa tingkat underpricing terkait juga dengan fenomena IPO yang lain yaitu adanya asimetri informasi 
(Tsang dan Belvins, 2015). Oleh karena itu untuk mengurangi tingkat underpricing, perusahaan yang memiliki risiko rendah berusaha untuk mengurangi asimetri informasi ini dengan mengungkapkan karakteristik dari risiko rendahnya ini ke pasar (Carter dan Manaster, 1990).

Pengungkapan merupakan salah satu cara yang dilakukan perusahaan untuk menyampaikan informasi perusahaan terhadap pasar atau investor. Pengungkapan ini dapat dibagi menjadi dua yaitu pengungkapan wajib dan pengungkapan sukarela. Pengungkapan wajib merupakan pengungkapan yang telah ditetapkan atau diharuskan oleh standar akuntansi atau regulator, sedangkan pengungkapan sukarela merupakan pengungkapan informasi yang ditambahkan oleh perusahaan secara sukarela selain dari pengungkapan yang diwajibkan oleh standar akuntansi atau regulator (Suwardjono, 2016).

Pengungkapan sukarela dipercaya dapat membantu mengurangi risiko underpricing di pasar perdana saham. Bahkan investor menganggap pengungkapan sukarela ini sebagai sinyal yang dapat membedakan perusahaan yang good news dari perusahaan yang bad news. Lev dan Penman (1990) menyatakan bahwa ramalan laba sebagai informasi yang secara sukarela diungkapkan oleh manajer ditangkap oleh investor sebagai informasi yang dapat dinilai kredibilitasnya sehingga informasi yang diungkapkan secara sukarela dapat membedakan perusahaan sebagai perusahaan yang good news. Bahkan investor akan menganggap perusahaan sebagai kemungkinan bad news jika tidak melakukan pengungkapan sukarela dan karena itu investor akan memberikan diskun terhadap nilai perusahaan (Glaeser et al., 2017).

Berdasarkan adanya fenomena IPO inilah penelitian ini bertujuan untuk menguji ada atau tidaknya hubungan antara nilai pasar penutupan pada hari pertama ketika IPO sebagai proksi reaksi pasar dengan pengungkapan sukarela. Kemudian penelitian ini juga bertujuan untuk menguji secara empiris ada atau tidaknya pengaruh dari pengungkapan sukarela yang ditangkap sebagai sinyal-sinyal oleh investor ketika IPO terhadap nilai perusahaan (firm value). Adapun jenis-jenis pengungkapan sukarela yang digunakan sebagai proksi pensinyalan ketika penawaran saham perdana adalah underwriter, auditor, ukuran perusahaan, dan persentase saham yang ditahan pemilik lama.

\section{KAJIAN LITERATUR DAN PENGEMBANGAN HIPOTESIS \\ Fenomena IPO}

Tidak diperolehnya dana secara maksimal oleh perusahaan yang melakukan penawaran perdana saham menjadi sebuah fenomena yang umum terjadi di bursa saham sehingga banyak penelitian dilakukan untuk menjelaskan mengapa fenomena IPO ini terjadi dan bagaimana risiko dari fenomena ini dapat diantisipasi atau setidaknya dikurangi. Fenomena IPO ini umum terjadi di setiap bursa saham di dunia (Kim et.al., 1993).

Di Korea, Kim et.al. (1993) menemukan bahwa tingkat underpricing ketika perusahaan melakukan IPO terkait dengan motif perusahaan melakukan go public di Korea Stock Exchange (KSE) dan investor lebih tertarik dengan return dari investasi mereka daripada terhadap nilai perusahaan investee. Hasil penelitian di Kanada dengan sampel perusahaan yang melakukan IPO dan mengumpulkan prospektus di Ontario Securities Commission menemukan bukti bahwa ramalan laba ditangkap sebagai sinyal dalam mengurangi asimetri informasi antara perusahaan dan investor sehingga memiliki pengaruh terhadap tingkat underpricing (Jog dan McConomy, 2003). Di Prancis, penelitian mengenai perusahaan IPO dikaitkan dengan hubungan struktur corporate governance perusahaan IPO dengan risiko kegagalan dan risiko delisting perusahaan IPO dalam jangka panjang (Anis, 2015), penelitian senada juga

JIAFE (Jurnal Ilmiah Akuntansi Fakultas Ekonomi)

Volume 3 No. 2 Tahun 2017, Hal. 32-42 
dilakukan di Spanyol oleh Alvarez-Otero dan Lopez-Iturriaga (2018) yang menguji hubungan antara proporsi saham yang dimiliki oleh dewan direksi terhadap tingkat underpricing.

Penelitian Sundarasen et.al. (2017) di Bursa Malaysia memperoleh bukti bahwa reputasi auditor dan underwriter ditangkap sebagai sinyal oleh investor yang mempengaruhi keputusan investasi mereka dan dapat mengurangi adanya asimetri informasi sehingga berpengaruh terhadap tingkat initial return perusahaan IPO. Sedangkan hasil penelitian terhadap saham IPO di Indonesia oleh Nurhidayati dan Indriantoro (1998) tidak dapat membuktikan bahwa underwriter, auditor, persentase saham yang ditahan pemilik lama, umur perusahaan, dan ukuran perusahaan mempengaruhi tingkat underpricing. Namun, penelitian Indriani dan Marlia (2014) pada perusahaan yang IPO tahun 2009 sampai 2013 di Bursa Efek Indonesia menemukan sebaliknya, bahwa underwriter dan leverage keuangan mempengaruhi tingkat underpricing saham sehingga mempengaruhi investor dalam melakukan penilaian terhadap perusahaan.

\section{Asimetri Informasi dan Teori Signalling}

Selain underpricing, fenomena IPO lain yang dianggap mempengaruhi tidak maksimalnya perolehan dana oleh perusahaan adalah adanya asimetri informasi. Bahkan terjadinya underpricing sering dikaitkan dengan adanya perbedaan informasi yang dimiliki oleh perusahaan dan investor (agen dan principal). Pada saat penawaran perdana, penentuan harga dilakukan oleh penerbit saham dan underwriter-nya, tetapi underwriter merupakan pihak yang paling mengetahui informasi mengenai pasar dan isu-isu tentang saham go public di pasar (Indriani dan Marliani, 2013) sehingga underwriter-lah yang akan memperoleh keuntungan untuk mengurangi risiko yang harus ditanggung apabila saham yang dijamin di pasar perdana tidak laku dan underwriter harus membeli sisa sahamnya (Nurhidayati dan Indriantoro, 1998).

Asimetri informasi menyebabkan kurangnya informasi yang diperoleh investor di bursa saham sehingga para investor menghadapi ketidakpastian dalam menentukan nilai perusahaan (Jog dan McConomy, 2003). Untuk mengurangi ketidakpastian yang dihadapi investor karena kurangnya informasi mengenai perusahaan, maka manajer melakukan pengungkapan secara sukarela mengenai informasiinformasi privat-nya, terutama informasi yang merupakan berita baik. Informasi yang ditambahkan dan diungkapkan secara sukarela inilah yang digunakan oleh perusahaan untuk mensinyalkan nilai perusahaan yang sebenarnya (Grinblatt dan Hwang, 1989).

Penelitian-penelitian selanjutnya mengenai asimetri informasi ketika IPO banyak yang menghubungkannya dengan pengungkapan sukarela sebagai sinyal atau dalam pensinyalan nilai perusahaan (signalling firm value). Pada tahun 1977, Leland dan Pyle telah menguji persentase kepemilikan yang ditahan oleh pemilik lama sebagai sinyal kepada investor, meski waktu itu pengujian hanya menggunakan satu parameter saja. Teori signalling kemudian juga dikaitkan dengan teori agensi dari Jensen dan Meckling (Morris, 1987) dan hasil penelitian menunjukkan bahwa kedua teori ini saling berhubungan yaitu asimetri informasi antara agen dan principal dapat dikurangi dengan adanya pensinyalan informasi seperti pemilihan kebijakan akuntansi oleh manajer perusahaan.

Sebenarnya perusahaan dapat saja mengungkapkan informasi mengenai nilai investasinya atau nilai perusahaannya ke pasar secara langsung. Namun, Bernhardt dan LeBlanc (1995) mengemukakan terdapat perbedaan mendasar antara pengungkapan langsung dengan pensinyalan yaitu 
pensinyalan merupakan komunikasi tidak langsung dan hanya menarik digunakan oleh perusahaan yang memiliki proyek yang lebih baik sehingga perusahaan dapat mengungkapkan "good news", tetapi tidak "nature of good news"-nya yang dapat ditiru oleh kempetitor atau "new entrance". Informasi yang terlalu banyak diungkapkan ke pasar memberikan kesempatan bagi kompetitor untuk meniru dan menyebabkan perusahaan memiliki risiko kehilangan investasi. Oleh karena itu, signalling lebih dipilih untuk menyampaikan informasi privat dibandingkan dengan pengungkapan langsung.

Penelitian mengenai teori signalling ini kemudian dikembangkan lagi dengan melibatkan jenis-jenis pengungkapan sukarela lain yang dapat digunakan sebagai media pensinyalan oleh manajer perusahaan. Selain pengembangan dari penelitian Leland dan Pyle tahun 1997 yang menggunakan proporsi saham yang dimiliki pemilik lama (Anis, 2015, Alvarez-Otero dan LopezIturriaga, 2018), penelitian-penelitian lain juga menguji pengaruh pensinyalan dengan menambahkan parameter sinyal-sinyal lainnya seperti underwriter sebagai penjamin emisi (Carter dan Manaster, 1990, Nasirwan, 2002, Migliorati dan Vismara, 2014, Lyanders, 2016), auditor sebagai advisor (Balvers et al., 1988, Menon dan William, 1991, Firth dan Liau-Tan, 1998, Choi dan Lee, 2014, Sundarasen, 2017), dan ukuran perusahaan (Nurhidayati dan Indriantoro, 1998, Rahbar dan Khodadady, 2015).

\section{Pengembangan Hipotesis}

Berdasarkan paparan di atas mengenai fenomena-fenomena IPO, dapat disimpulkan bahwa manajer perusahaan berusaha mengurangi asimetri informasi antara perusahaan dengan investor untuk mengurangi risiko tidak maksimalnya perolehan dana ketika go public dengan secara sukarela mengungkapkan informasi privat-nya (underwriter, auditor, ukuran perusahaan, dan persentase saham yang ditahan pemilik lama) sebagai pensinyalan nilai perusahaan. Oleh karena itu penelitian ini mengembangkan hipotesis pertama sebagai berikut:

\section{Hipotesis 1}

H1: Terdapat hubungan antara underwriter, auditor, ukuran perusahaan, dan persentase saham yang ditahan pemilik lama dengan nilai pasar penutupan pada hari pertama ketika IPO.

Kemudian, penelitian ini juga mengembangkan hipotesis yang kedua untuk menjawab seberapa besar pengaruh dari jenis-jenis sinyal yang digunakan manajer dalam pensinyalan nilai perusahaan.

\section{Hipotesis 2}

H2: Underwriter, auditor, ukuran perusahaan, dan persentase saham yang ditahan pemilik lama berpengaruh terhadap nilai perusahaan.

\section{METODA PENELITIAN Data dan Deskripsi Sampel}

Sampel yang digunakan dalam penelitian ini terdiri dari perusahaan yang melakukan IPO di Bursa Efek Indonesia (BEI) dengan kriteria sebagai berikut:

1. Perusahaan melakukan IPO antara Januari 2015 dan Desember 2017 (berdasarkan tanggal listing di BEI).

2. Perusahaan menerbitkan saham yang sebelumnya tidak diperdagangkan (saham IPO).

3. Perusahaan menyajikan laporan keuangan dalam Rupiah.

4. Perusahaan menerbitkan prospektus dan mencantumkan nama underwriter, auditor, total aset, dan persentasi jumlah saham yang dimiliki pemegang lama di prospektusnya.

Sedangkan data perusahaan yang listing di Bursa Efek Indonesia bersumber dari

JIAFE (Jurnal Ilmiah Akuntansi Fakultas Ekonomi)

Volume 3 No. 2 Tahun 2017, Hal. 32-42 
www.idx.co.id, dan data untuk mengukur variabel independen yaitu underwriter, auditor, total aset, dan persentase kepemilikan yang ditahan pemilik lama bersumber dari prospektus yang diunduh dari www.ticmi.co.id. Kemudian harga saham penutupan pada hari pertama ketika IPO yang digunakan untuk mengukur variabel dependen diperoleh dari TICMI.

Sesuai dengan kriteria di atas, dari periode 2015 sampai 2016 terdapat 70 perusahaan yang melakukan penawaran umum perdana. Namun, hanya 58 perusahaan yang dapat digunakan dalam penelitian ini karena 6 di antaranya tidak memiliki prospektus dan 6 perusahaan lagi menyajikan laporan keuangannya dalam mata uang dolar sehingga dikeluarkan dari sampel.

\section{Variabel Independen}

\section{Underwriter (UNDW)}

Seperti telah dijelaskan sebelumnya bahwa underwriter memiliki peran dalam penentuan harga saham pada saat ditawarkan pertama kali. Pemilihan underwriter sebagai penjamin saham mempengaruhi keputusan investasi, apalagi di Indonesia, karena underwriter memberikan penjaminan penuh yaitu tipe penjaminan yang berisiko tinggi (full commitment) (Nurhidayati dan Indriantoro, 1998). Selain itu reputasi underwriter juga berhubungan dengan tingkat return dan kinerja saham IPO dalam jangka panjang (Carter dan Manaster, 1990, Carter et al., 1998). Hasil senada dikemukakan oleh Nasirwan (2002) yaitu reputasi penjamin emisi berasosiasi secara statistis siginifikan dengan return awal, return 15 hari setelah IPO, dan kinerja saham satu tahun setelah IPO. Bahkan, tingginya reputasi penjamin emisi berasosiasi dengan rendahnya tingkat underpricing (Migliorati dan Vismara, 2014), oleh karena itu reputasi underwriter dapat digunakan untuk mengurangi asimetri informasi dan signalling firm value kepada investor yang potensial (Sundarasen, 2017).

Penelitian ini mengukur variabel underwriter dengan menggunakan modifikasi pemeringkatan dari Carter dan Manaster (1990) yang membagi peringkat underwriter ke dalam 9 peringkat dan berdasarkan pada besarnya nilai saham yang ditangani oleh underwriter. Terdapat 26 underwriter yang termasuk pada pemeringkatan ini, pada peringkat 9 adalah PT Bahana Sekuritas sebagai underwriter yang menangani nilai saham paling besar, dan peringkat 1 ditempati oleh PT Artha Sekuritas.

\section{Auditor (AUDT)}

Menon dan Williams

menyatakan bahwa kredibilitas laporan keuangan auditan tergantung dari kualitas hasil audit, tetapi karena kualitas audit sulit untuk dikaji maka auditor akan berusaha mengkomunikasikan kualitas audit mereka melalui nama dan reputasinya. Bagi manajer, nama dan reputasi auditor ini menjadi salah satu media yang dapat digunakan untuk mensinyalkan bahwa mereka memiliki informasi privat yang kredibel (Datar et al., 1991). Bahkan reputasi auditor terbukti berpengaruh signifikan terhadap rendahnya tingkat underpricing ketika IPO (Balvers et al., 1988, Firth dan Liau-Tan, 1998) dan tingginya return awal perusahaan IPO, serta dianggap sebagai sinyal kredibilitas perusahaan IPO oleh investor (Sundarasen, 2017).

Studi ini menggunakan auditor sebagai salah satu jenis pensinyalan. Sebagai variabel independen, auditor ini diukur dengan membedakan antara auditor yang termasuk the Big 4 auditor dengan yang bukan the Big 4 auditor. Menurut Graven dan Taylor (2015) besarnya ukuran kantor auditor menunjukkan bahwa auditor tersebut lebih berpengalaman dan lebih ahli, serta memiliki kebijakan yang lebih tegas untuk menjamin kualitas audit mereka.

Kemudian, auditor yang termasuk ke dalam Big 4 auditor diberi nilai 1, sementara 
yang tidak termasuk ke dalam Big 4 auditor memiliki nilai 0 . Auditor yang termasuk ke dalam the Big 4 ini terdiri dari KAP Tanudiredja, Wibisana \& Rekan (PricewaterhouseCoopers), KAP Osman Bing Satrio (Deloitte), KAP Purwantono, Suherman \& Surja (Ernst and Young), serta KAP Sidharta dan Widjaja (KPMG).

\section{Ukuran Perusahaan (SIZE)}

Penelitian Nurhidayati dan Indriantoro (1998) menunjukkan bahwa ukuran perusahaan tidak mempengaruhi tingkat underpricing yang terjadi ketika IPO. Meskipun demikian, penelitian-penelitian lain membuktikan bahwa ukuran suatu perusahaan berpengaruh terhadap keputusan investor (Islam at al., 2010, Rahbar dan Khodadady, 2015).

Dalam fenomena asimetri informasi, ukuran perusahaan merupakan salah satu sinyal yang dilepas oleh manajer untuk mengisyaratkan nilai perusahaan kepada investor. Oleh karena itu, studi ini menggunakan ukuran perusahaan sebagai salah satu jenis informasi yang diungkapkan secara sukarela untuk mensinyalkan nilai perusahaan. Variabel ini diukur dengan total aset yang dimiliki perusahaan pada laporan keuangan sebelum IPO.

\section{Persentase Kepemilikan (INSD)}

Variabel independen terakhir yang digunakan dalam studi ini adalah persentase kepemilikan yang ditahan pemilik lama. Proporsi kepemilikan ini ketika perusahaan melakukan IPO ditangkap sebagai pensinyalan dari nilai perusahaan. Investor memandang bahwa yang lebih mengetahui mengenai aliran kas di masa depan perusahaan adalah pengusaha (pemegang lama) sehingga jika mereka mengetahui bahwa aliran kasnya bagus maka pemegang lama ini cenderung akan menahan sebagian besar proporsi kepemilikan mereka (Leland dan Pyle, 1977, Downes dan Heinkel, 1982). Kemudian penelitian selanjutnya mengenai persentase kepemilikan yang ditahan pemilik lama (retained ownership) ini dikembangkan untuk menguji pengaruhnya terhadap fenomena IPO seperti underpricing, asimetri informasi, dan initial return (Kim et al., 1993, Firth, 1998, Nasirwan, 2002, Islam, 2010, dan Alvarez-Otero dan Lopez-Iturriaga, 2018).

Oleh karena itu, persentase saham yang ditahan pemiliki lama juga dapat digunakan oleh manajer untuk pensinyalan nilai perusahaan mereka terhadap investor. Proporsi kepemilikan ini diukur dengan persentase saham yang masih ditahan oleh pemilik lama ketika IPO sudah dilakukan.

\section{Variabel Dependen \\ Harga Saham Hari Pertama IPO (MV)}

Variabel ini diukur dengan menggunakan nilai pasar penutupan hari pertama ketika perusahaan melakukan penawaran perdananya. Nilai pasar penutupan pada hari pertama ketika IPO (MV) ini sebenarnya merupakan salah satu indikator atau komponen untuk mengukur tingkat underpricing yang dihitung dari harga penutupan hari pertama ketika IPO dikurangi harga penawaran perdana (Jog dan McConomy, 2003).

Namun, penelitian ini tidak menggunakan tingkat underpricing sebagai proksi reaksi pasar terhadap adanya sinyalsinyal yang diungkapkan secara sukarela dikarenakan model ini memiliki kelemahan. Pada model underpricing manajemen diasumsikan telah mengetahui bagaimana nilai pasar saham atau penawaran setelah listing (Firth, 1998).

\section{Nilai Perusahaan (FV)}

Variabel dependen ini diukur dengan cara mengkapitalisasi nilai pasar saham pada penutupan hari pertama ketika IPO yang dihitung dengan mengkalikan harga saham pada penutupan hari pertama ketika IPO dengan jumlah saham yang beredar setelah penawaran IPO. Penggunaan harga saham pada penutupan hari pertama ketika IPO

JIAFE (Jurnal Ilmiah Akuntansi Fakultas Ekonomi)

Volume 3 No. 2 Tahun 2017, Hal. 32-42 
digunakan karena harga saham ini lebih mencerminkan nilai intrinsik saham daripada harga saham penawaran perdana dengan demikian lebih mencerminkan nilai intrinsik perusahaan juga (McGuinness, 1993).

\section{Analisis Data}

Sebelum pengujian data dilakukan untuk menunjukkan hubungan pengungkapan sukarela dengan nilai pasar hari pertama ketika IPO dan pengaruhnya terhadap nilai perusahaan, terlebih dahulu penelitian ini melakukan asumsi klasik terhadap data supaya layak uji. Asumsi klasik ini meliputi uji normalitas data, autokorelasi, multikolineritas, dan heteroskedastisitas. Hipotesis 1 diuji dengan menggunakan metoda korelasi antar variabel. Sedangkan hipotesis 2 diuji dengan menggunakan metoda analisis regresi linier berganda. Berikut disajikan persamaan regresi linier berganda yang digunakan dalam penelitian ini:

$F V=a+b_{1}($ UNDW $)+b_{2}($ AUDT $)+b_{3}($ SIZE) + $b_{4}$ (INSD)

Keterangan:

$\begin{array}{lll}\text { FV } & = & \text { Nilai perusahaan } \\ \text { UNDW } & =\text { Underwriter (reputasi } \\ & =\text { penjamin emisi) } \\ \text { AUDT } & \text { Reputasi auditor } \\ \text { SIZE } & \text { Ukuran perusahaan } \\ \text { INSD } & =\text { Persentase jumlah saham } \\ & \text { yang ditahan pemilik lama }\end{array}$

\section{HASIL DAN PEMBAHASAN}

Hasil pengujian menunjukkan bahwa setelah dilakukan uji kelayakan data, data yang digunakan dalam penelitian ini layak uji. Data berdistribusi secara normal terbukti dengan nilai Kolmogorov-Smirnov 0,248> dari nilai signifikansi 0,05 dan pada diagram P-Plot data menyebar di sekitar garis diagonal serta mengikuti garis diagonal. Data juga tidak memiliki masalah autokorelasi dan multikolinearitas antar variabel. Nilai Durbin-
Watson berada di antara $1,7259<2,130<$ 2,2741 sedangkan nilai tolerance $>0,1$ dan $\mathrm{VIF} \leq 10$ untuk semua variabel independen. Kemudian untuk asumsi klasik yang terakhir, data tidak memiliki masalah heteroskedastisitas karena pada diagram scatterplot data menyebar secara merata di sekitar nol dan tidak membentuk pola tertentu.

Tabel 1

Ukuran Normalitas

\begin{tabular}{lc}
\hline Independen variabel & Durbin-Watson \\
\hline UNDW, AUDT, SIZE, INSD & 2.130 \\
\hline
\end{tabular}

Sumber: Hasil olah SPSS 22

Tabel 2

Ukuran Tolerance dan VIF

\begin{tabular}{lcc}
\hline Variabel & \multicolumn{2}{c}{ Colienarity Statistics } \\
& Tolerance & VIF \\
\hline UNDW & 0,879 & 1,1138 \\
AUDT & 0,983 & 1,017 \\
SIZE & 0,867 & 1,154 \\
INSD & 0,956 & 1,046 \\
\hline
\end{tabular}

Sumber: Hasil olah SPSS 22

\section{Hasil Hipotesis}

Hipotesis 1 ditujukan untuk menguji ada atau tidaknya hubungan antara setiap jenis pengungkapan sukarela dengan nilai pasar penutupan hari pertama ketika IPO sebagai proksi reaksi pasar. Hipotesis ini diuji dengan menggunakan metoda korelasi. Hasilnya menunjukkan bahwa antara variabel UNDW, AUDT, SIZE, dan INSD sebenarnya memiliki hubungan dengan nilai pasar penutupan ketika IPO tetapi tidak signifikan. Seperti terlihat dalam Tabel 3 bahwa signifikansi 2-tailed untuk UNDW 0,319> 0,05 , AUDT 0,814 >0,05, SIZE 0,644 >0,05, dan INSD 0,295 lebih besar daripada nilai signifikansi 0,05. 
Tabel 3

Hasil Uji Korelasi

\begin{tabular}{|l|c|c|}
\hline Variabel & $\mathbf{r}$ & Sig. (2-Tailed) \\
\hline UNDW & 0,133 & 0,319 \\
\hline AUDT & $-0,032$ & 0,814 \\
\hline SIZE & 0,062 & 0,644 \\
\hline INSD & 0,140 & 0,295 \\
\hline
\end{tabular}

Variabel dependen MV

Sumber: Hasil olah SPSS 22

Begitu pula dengan pengujian hubungan UNDW, AUDT, SIZE, dan INSD secara bersama-sama terhadap nilai pasar penutupan hari pertama ketika IPO, uji korelasi ganda tidak dapat menunjukkan hubungan dan signifikansi antar variabel tersebut dengan $\mathrm{R} \quad 0,205$ dan tingkat signifikansi $0,677>$ daripada tingkat signifikansi 0,05. Oleh karena itu dapat dikatakan bahwa UNDW, AUDT, SIZE, dan INSD tidak memiliki hubungan signifikan dengan nilai pasar penutupan pada hari pertama ketika IPO sebagai proksi reaksi pasar.

Tabel 4

Hasil Uji Korelasi Ganda

\begin{tabular}{lll}
\hline Variabel & R & R Square
\end{tabular}

UNDW, AUDT, SIZE, INSD

0,205

0,042

Sumber: Hasil olah SPSS 22

Selanjutnya pengujian hipotesis akan menjawab pertanyaan apakah ada atau tidak pengaruh pengungkapan sukarela UNDW, AUDT, SIZE, dan INSD terhadap pensinyalan nilai perusahaan (hipotesis 2). Metoda penelitian yang digunakan adalah model regresi berganda dengan menggunakan kapitalisasi nilai saham penutupan pada hari pertama ketika IPO (variabel dependen) sebagai proksi nilai perusahaan yang diharapkan dapat disinyalkan oleh manajer perusahaan.

Hasil uji $t$ terhadap variabel menunjukkan bahwa secara parsial ukuran perusahaan (SIZE) memiliki pengaruh sebesar 2,892 dan ini lebih besar daripada $t$ tabel yang hanya sebesar 2,004 dengan tingkat signifikansi $0,006<0,05$. Sedangkan variabel lainnya yang terdiri dari UNDW, AUDT, dan INSD tidak dapat dibuktikan memiliki pengaruh secara parsial terhadap pensinyalan nilai perusahaan. Nilai hitung t untuk UNDW, AUDT, dan INSD lebih kecil daripada nilai $t$ tabel yang sebesar 2,004 (dapat dilihat pada tabel 5).

\begin{tabular}{lcc} 
& $\begin{array}{c}\text { Tabel } \mathbf{5} \\
\text { Uji t }\end{array}$ & \\
\hline Variabel & $\mathbf{t}$ & Sig. \\
\hline UNDW & 1,143 & 0,258 \\
AUDT & 0,064 & 0,949 \\
SIZE & 2,892 & 0,006 \\
INSD & 0,162 & 0,872 \\
\hline
\end{tabular}

Sumber: Hasil olah SPSS 22

Meski pada uji $t$, penelitian ini tidak dapat membuktikan pengaruh secara parsial untuk tiga jenis pengungkapan sukarela, analisis uji $F$ terhadap semua variabel menunjukkan bahwa secara bersama-sama variabel-variabel underwriter, auditor, ukuran perusahaan, dan persentase saham yang ditahan pemilik lama mempengaruhi nilai perusahaan pada saat IPO. Nilai $F$ hitung

AeljailstedoBar dafipota $F$ tabel $(3,401>2,54)$

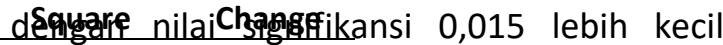

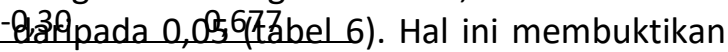
bahwa variabel-variabel ini berpengaruh terhadap penilaian investor ketika IPO secara serempak.

\begin{tabular}{lccc} 
& \multicolumn{2}{c}{$\begin{array}{c}\text { Tabel } 6 \\
\text { Uji F }\end{array}$} \\
& \multicolumn{1}{c}{$\mathbf{F}$} & Sig. \\
\hline Variabel & & 3,401 & 0,015 \\
\hline $\begin{array}{l}\text { UNDW, AUDT, } \\
\text { INSD }\end{array}$ & & & \\
\hline
\end{tabular}

Sumber: Hasil olah SPSS

\section{PENUTUP}

Penelitian ini bertujuan untuk menguji bahwa terdapat hubungan dan pengaruh antara pengungkapan sukarela dengan pensinyalan nilai perusahaan (signalling firm value). Pensinyalan nilai perusahaan ini dilakukan oleh perusahaan untuk mengurangi risiko perusahaan tidak mendapatkan dana secara maksimal ketika mereka melakukan penawaran saham perdananya yang

JIAFE (Jurnal Ilmiah Akuntansi Fakultas Ekonomi)

Volume 3 No. 2 Tahun 2017, Hal. 32-42 
disebabkan oleh fenomena IPO. Hasil penelitian menunjukkan bahwa baik secara parsial dan bersama-sama sinyal underwriter, auditor, ukuran perusahaan, dan persentase saham yang ditahan pemilik lama tidak dapat dibuktikan memiliki hubungan yang signifikan dengan nilai pasar penutupan pada hari pertama ketika IPO.

Namun hasil dari pengujian regresi berganda membuktikan ukuran perusahaan secara parsial mempengaruhi nilai perusahaan sehingga dapat disimpulkan bahwa investor menangkap sinyal ini lebih kuat daripada sinyal-sinyal yang lain. Selain itu, hasil pengujian menunjukkan tidak hanya sinyal ukuran perusahan yang mempengaruhi keputusan investasi dari investor, hasil uji $\mathrm{F}$ membuktikan investor secara simultan menggunakan semua variabel pensinyalan dalam mempertimbangkan investasinya.

Penelitian ini dapat memberikan manfaat bagi manajer dan investor terutama dalam mengurangi kekurangan informasi ketika IPO, tetapi penelitian ini juga memiliki keterbatasan waktu dan jumlah sampel yang digunakan yaitu hanya tiga tahun terakhir dari 2015 sampai 2017 dengan sampel 58 perusahaan. Kemudian peringkat auditor hanya dibagi menjadi dua kategori sehingga tidak bisa secara akurat memberikan pemeringkatan. Oleh karena itu untuk penelitian selanjutnya akan lebih baik jika periode penelitian diperpanjang dengan jumlah sampel yang lebih banyak. Peringkat auditor juga diklasifikasikan dengan kategori yang lebih akurat misalnya dengan menggunakan kriteria spesialisasi auditor. Sedangkan untuk jenis pensinyalan dapat ditambahkan tipe pengungkapan sukarela yang lain misalnya ramalan laba (earning forecast).

\section{DAFTAR PUSTAKA}

Alvarez-Otero, Susana dan Lopez-Iturriaga, Felix J., "Does Corporate Governance Affect the Valuation of Spanish IPOs? The Role of Ownership Structure and the Board of Directors", Spanish Journal of Accounting and Finance, (Januari, 2018), hal 1-28.

Balvers, Ronald J., McDonald, Bill, dan Miller, Robert E., "Underpricing of New Issues and the Choice of Auditor as a Signal of Investment Banker Reputation", The Accounting Review, (Oktober, 1988), hal 605-622.

Bernhardt, Dan, dan LeBlanc, Greg, "Direct Revelation versus Signalling", Canadian Journal of Economics, 1995, hal 858885.

Carter, Richard, dan Manaster, Steven, "Initial Public Offerings and Underwriter Reputation", The Journal of Finance, Vol. XLV (4), (September, 1990), hal 1045-1067.

Choi, Jong-Hag, dan Lee, Woo-Jong, "Association Between Big 4 Auditor Choice and Cost of Equity Capital for Multiple-Segment Firms", Accounting and Finance, 54, 2014, hal 135-163.

Chua, Ansley, "Market Conditions, Underwriter Reputation, and First day Return of IPOs", Journal of Financial Markets, Vol. 19 1914, hal 1-23.

Datar, Srikant M., Feltham, Gerald A., Hughes, John S., "The Role of Audits and Audit Quality in Valuing New Issues", Journal of Accounting and Economics, Vol 14, 1991, hal 3-49.

Djerbi Jarboui Anis, Chiraz,"Boards, Retained Ownership, and Failure Risk of French IPO Firms", Corporate Governance: The International Journal of Business in Society, Vol. 15, 2015, hal 1-19.

Downes, David H., dan Heinkel, Robert, "Signaling and the Valuation of Unseasoned New Issues", The Journal of Finance, Vol XXXVII (1), Maret 1982, hal 1-10.

Firth, Michael, "IPO Profit Forecasts and Their Role in Signalling Firm Value and Explaining Post-Listing Returns", Applied Financial Economics, 1998 (8), hal 29-39. 
Firth, Michael, dan Liau-Tan, Chee Keng, "Auditor Quality, Signalling, and the Valuation of Initial Public Offerings", Journal of Business Finance and Accounting, (Januari/Maret, 1998), hal 1445-165.

Glaeser, Stephen, Michels, Jeremy, dan Verrecchia, Robert E., "Discretionary Disclosure and Manager Horizon", 2016 Carnegie Mellon Accounting Summer Symposium and Wharton, the Wharton School of the University of Pennsylvania.

Garven, Sarah, dan Taylor, Gary, "Big 4 Auditor Office Size, Analyst's Annual Earnings Forecasts and Client Earnings Management Behavior", Academy of Accounting and Financial Studies Journal, Vol 19 (3), 2015, hal 103-124.

Grinblatt, Mark, dan Hwang, Chuan Yang, "Signalling and the Pricing of New Issues", The Journal of Finance, (June, 1989), hal 393-420.

Indriani, Susi, dan Marlia, Sri, "The Evidence of IPO Underpricing in Indonesia 2009 - 2013", Review of Integrated Business and Economics Research, Vol 4 (1) 2014, hal 299-316.

Islam, Md. Aminul, Ali, Ruhani, dan Ahmad, Zamri, "An Empirical Investigation of the Underpricing of Initial Public Offerings in the Chittagong Stock Exchange", International Journal of Economics and Finance, Vol 2 (4), 2010, hal 36-46.

Kim, Jeong-Bon, Krinsky, Itzhak, dan Lee, Jason, "Motives for Going Public and Underpricing: New Findings from Korea", Journal of Business Finance and Accounting, (Januari, 1993), hal 195-211.

Leland, Hayne, dan Pyle, David, "Information Asymmetries, Financial Structure, and Financial Intermediation", Journal of Finance 32, 1977, hal 371-387.

Lyanders, Evgeny, Fu, Fangjian, dan Li, Erica X.N., "Do Underwriters Compete in IPO
Pricing?", Management Science, 2016, hal 1-31.

McGuinness, Paul, "The Market Valuation of Initial Public Offerings in Hong Kong", Applied Financial Economics, Vol 3, 1993, hal 267-281.

Menon, Krishnagopal, dan William, David, D., "Auditor Credibility and Initial Public Offerings", The Accounting Review", Vol 66 (2), 1991, hal 313-332.

Migliorati, Katrin, dan Visamara, Silvio, "Rankings Underwriters of European IPOs", European Financial Management, Vol. 20 (5), 2014, hal 891-925.

Morris, Richard D., "Signalling, Agency Theory, and Accounting Policy Choice", Accounting and Business Research, Vol 18 (69), 1987, hal 47-56.

Nasirwan, 2002, "Reputasi Penjamin Emisi, Return Awal, Return 15 Hari Sesudah IPO, dan Kinerja Perusahaan Satu Tahun Sesudah IPO di BEJ", Jurnal Riset Akuntansi Indonesia, Vol 5 (1), Januari 2002, hal 64-77.

Nurhidayati, Siti, dan Indriantoro, Nur, "Analisis Faktor-faktor yang Berpengaruh terhadap Tingkat Underpriced pada Penawaran Perdana di Bursa Efek Jakarta", Jurnal Ekonomi dan Bisnis Indonesia, Vol 13. No. 1. 1998, hal 21-30.

Rahbar, Mohsen, dan Khodadady, Davood, "Studying the Relationship between Company Size, Earnings Management in Initial Public Offerings of Stock and Performance of the Company Listed on Tehran Stick Exchange", Asian Social Science, Vol. 11 (24), 2015, hal 293300.

Ritter, Jay R., "The Long-Run Performance of Initial Public Offerings", The Journal of Finance, Vol. XLVI (1), 1991, hal 3-26.

Sundarasen, Sheela D., Khan, Afzal, Rajangam, Nakiran, "Signalling Roles of Prestigious Auditors and Underwriters

JIAFE (Jurnal Ilmiah Akuntansi Fakultas Ekonomi)

Volume 3 No. 2 Tahun 2017, Hal. 32-42 
in an Emerging IPO Market", Global Business Review, 19-I, 2017, hal 1-16.

Suwardjono, "Teori Akuntansi: Perekayasaan Pelaporan Keuangan", Edisi Ketiga, 2016, BPFE, Yogyakarta.

Tsang, Eric WK., Blevins, Dane P., "A Critique of the Information Asymmetry Argument in the Management and Entrepreneurship Underpricing Literature", Strategic Organization, Vol 13,2015 , hal 1-12.

https://gopublicidxcoid.files.wordpress.com/ 2017/10/pengalaman-underwriterindonesia.pdf, diunduh tanggal 13 April 2018.

http://pppk.kemenkeu.go.id/News/Details/1 8, diunduh tanggal 13 April 2018. 